\title{
Ecuadorian Landscape National legislation contrasted to regional and international landscape policies
}

\author{
El Paisaje Ecuatoriano \\ La legislación nacional en contraste con las políticas nacionales e \\ internacionales de paisaje
}

\section{Abstract}

Autores:

Arq. Soledad Moscoso soledad.moscoso@ucuenca.edu.ec

Arq. Anja Louisa María Wijffels

Arq. Sebastián Astudillo sebastian.astudillo@ucuenca.edu.ec

Dr. Arq. Fausto Cardoso

fausto.cardoso@ucuenca.edu.ec

Proyecto vlirCPM Facultad de Arquitectura y Urbanismo

Universidad de Cuenca

Ecuador

Recibido: 16 Feb 2015 Aceptado: 2 Abr 2015

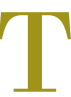

he geographic location of Ecuador together with its wide altitude range as well as volcanic activity related to the Andean uplift, has granted it a privileged natural landscape characterized by its high biodiversity and exceptional view-sheds. Ecuador has three World Heritage Sites that are located along the glacial valleys and mountain chains of the Andean Mountain Range, where pronounced slopes and constantly changing land use makes them especially vulnerable to landscape alterations. Ecuadorian landscapes are exclusive testimonies of human interaction with the natural environment, giving way to cultural landscapes with prominent historic value. This paper pretends to make some recommendations to develop policies regarding the protection of Ecuadorian landscapes. The aim is to contribute to the debate by reflecting on the current national policies and regulations regarding Landscape and comparing them with the state of art in the region and the rest of the world.

Keywords: heritage legislation, ecuadorian landscape policies, cultural landscape policies.

\section{Resumen:}

La ubicación geográfica del Ecuador conjuntamente con su topografía, le ha dotado de un paisaje natural privilegiado que se caracteriza por su alta biodiversidad y excepcionales vistas. Ecuador cuenta con tres sitios del patrimonio mundial que se encuentran a lo largo de los valles glaciares y las cadenas montañosas de la Cordillera de los Andes, donde las pendientes pronunciadas y en constante cambio del uso del suelo lo hacen especialmente vulnerable a alteraciones del paisaje. Los paisajes ecuatorianos dan testimonio de la interacción humana con el medio natural, dando origen a paisajes culturales de destacado valor histórico. Este artículo busca hacer algunas recomendaciones políticas relativas a la protección de los paisajes ecuatorianos. El objetivo es contribuir al debate mediante una reflexión sobre las políticas nacionales y regulaciones relativas al paisaje y compararlas con el estado del arte en la región y el resto del mundo.

Palabras clave: Legislación patrimonial, políticas ecuatorianas sobre paisaje, políticas sobre paisaje cultural. 


\section{Introduction}

Ecuador's geographic location, next to the Pacific Ocean, crossed by the Andean Mountains and sharing part of the Amazonia with neighboring countries, has granted it a privileged natural landscape.

From the cultural point of view, Ecuador is rich in material and nonmaterial heritage elements; there are two natural and three cultural World Heritage Sites. Among them there are two cities that keep their colonial grid plan and are located in the interandean valleys of the Andes Mountain Range ${ }^{1}$. Third, the country is crossed by the Qhapaq Ñan (English: Andean Road System, meaning "the beautiful road") extending along more than $6000 \mathrm{~km}$ from Colombia to Argentina and as such already an indicator of the spectacular interactions of humans with these extreme natural environment throughout history, providing the cultural landscapes with outstanding universal value.

The topographic characteristics together with the glacier formation of its valleys, the volcanic activity, the wide range of climatic conditions, among other unique characteristics, have granted to the Ecuadorian landscapes charm but also fragility from the landscape perspective. In spite of these special characteristics, the country has not yet generated any explicit and applicable policy regarding the landscape.

\section{Landscape Policies Evolution}

Since the first heritage charters a broader appreciation of heritage objects has surged, progressively including characteristics related to the (natural or built) surroundings. Already the Athens Charter (1931) pays attention to the protection of the surrounding areas of historic sites ${ }^{2}$. The Charter of Venice (1964) promotes caretaking of the building scale and the nearby built context or the setting ${ }^{3}$ of monuments. ${ }^{4}$

In 1976 the UNESCO approves the "Recommendation concerning the safeguarding and contemporary role of

\footnotetext{
1 The historic centres of Cuenca and Quito, Galapagos and Sangay National Parks and the Qhapaq Ñan are the Ecuadorian World Heritage Sites

${ }^{2}$ The Athens Charter for the Restoration of Historic Monuments, 1931, Art.7.

${ }^{3}$ The Venice Charter, 1964, Art. 6

${ }^{4}$ The Venice Charter, 1964, Art. 7 .
}

historic areas", putting special interest in the environment of the historic groups of buildings. ${ }^{5}$

It is only in 2000 where real advance is made including the specific term of "landscape heritage" in the Krakow Charter (2000). The charter suggests that landscape heritage is one of the conservation targets together with architectural and urban heritage ${ }^{6}$. The main values identified in cultural landscapes are lightened and in the case of urban areas they are related to their settlement, the relationship among built areas and open spaces, specific building appearance aspects, the natural surroundings and their functional use overtime.

The Krakow Charter includes an article that discusses landscape as cultural heritage emphasizing the need to understand and respect their character and to apply appropriate laws and norms to harmonize relevant territorial functions with essential values. In order to integrate landscape conservation, sustainable development, ecological activities, and natural environment require awareness and understanding of the relationships over time. ${ }^{7}$

Simultaneously a very important initiative was taken by creating a stronger legal corpus for the protection of heritage at the continental level, through the European Landscape Convention (Florence Convention), adopted in October 2000 and promoted by the member States of The Council of Europe. Beyond definitions ${ }^{8}$ the main contribution is to guarantee the varied engagements by the state parties. ${ }^{9}$ The State Parties are encouraged to undertake projects for awareness-raising and education as well as to promote the formation of specialists related to landscape protection. Others are the analysis of the characteristics of each landscape and to identify the pressures that are transforming them in order to create instruments to protect and manage them. ${ }^{10}$

Not only for the first time the concept of cultural landscape is included as a character for international legislation, the European Landscape Convention also inspired the creation of several national charters in the Americas (excepting Ecuador) and motivated the introduction the figure of landscape into national legislation.

For urban areas, the UNESCO - through the Vienna Memorandum (2005) - introduced a new trend regarding cultural landscape management promoting the Historic Urban Landscape approach. This particularity suggests the need for management tools for cultural landscapes in rural areas as well.

\footnotetext{
Recommendation concerning the Safeguarding and Contemporary Role of Historic Areas, 1976, Art. 1b.

${ }^{6}$ The Charter of Krakow , 2000, Art.1.

${ }^{7}$ The Charter of Krakow, 2000, Art.9-

${ }^{8}$ European Landscape Convention, 2000, Art. 1.

${ }^{9}$ European Landscape Convention, 2000, Art. 5.

${ }^{10}$ European Landscape Convention, 2000, Art. 6.
} 
Beyond the governmental initiatives there are some nonprofit organizations such as the International Federation of Landscape Architects (IFLA) that promote the idea of an international landscape convention. The proposal focuses on the relationship between people and their physical environment, landscape as a cultural and natural concept, a physical and abstract entity, having economic and social value. The concept integrates nature and culture and deals with protection of the past as well as the shaping of the future. ${ }^{11}$

\section{Latin American}

\section{landscape protection legislation}

The willingness to protect the landscape in Latin America will arrive several years after the European Landscape Convention. The International Federation of Landscape opened the discussion in the region, encouraging the elaboration of specific national charters as a first step towards the creation of an international landscape convention. Indeed the LALI (the Latin American Landscape Initiative) declaration of fundamental ethical principles suggests the fostering of the recognition, valuation, protection, management, and sustainable planning landscapes by means of the adoption of agreements that recognize local, regional, and national diversity and values of landscape, as well as principles and processes to safeguard it. ${ }^{12}$

The first attempts to protect landscapes came from Colombia, Costa Rica and Brazil in 2010.Very soon other countries would adopt similar charters fit to their landscape particularities. Ecuador is one of the very few countries in the Americas where the establishment of specific norms regarding landscape management and care are still missing. Most of the national charters relate to landscape design but nevertheless include the cultural dimension of landscape. Even if the charters don't have an specific legal value, they are an initial contribution to the debate about landscape conservation.

From the comparison among the Latin American charters (Table 1 ) it is possible to see deep similarities in their landscape definition merging environmental and cultural aspects. Landscape is seen as a way to motivate social and sustainable development, wellbeing and happiness among their nationals, by means of cultural identification, education and research, amongst others. Management is seen as a priority need while respecting social diversity and historic traditions.

At the same time initiative is taken in to consolidate a regional position towards landscape protection,

\footnotetext{
${ }^{11}$ (Towards and International Landscape Convention, 2013)

12 (Latin American Landscape Initiative)

${ }^{13}$ Carta Iberoamericana de Paisaje Cultural, 2012, Art.4
}

specifically concerning cultural landscape. In November 2012 the II Encounter on Cultural Landscapes took place in Cartagena de Indias (Colombia) giving way to the subscription of the Cultural Landscape Charter for the Americas and Spain (Carta Iberoamericana del Paisaje Cultural). The aim of this charter is to unify criteria to identify, recognize, and protect heritage landscapes as well as to create principles to analyze the historic evolution of cultural landscapes, to maintain their values and to conserve them for the collective wellbeing. ${ }^{13}$

It promotes the creation of opportunities to increment memory, knowledge and identity for the region and stresses the need to include the stakeholders and promote citizen participation through the creation of communication mechanisms. Proper management of the cultural landscape from an integrative position should consider the following aspects: Documentation, which can be understood as granting accurate studies, that enlighten the nowadays and future threats; physical and social project effects; Participation; sustainability: regarding environmental, social, economic, morphological, and landscape parameters; consciousness rising.

One of the biggest differences with the European Landscape Convention is that the implementation and approval by the national parties is problematic since there is no executive organism that makes it mandatory to the state members to accept it and implement it signed the charter. Only participants of the conference signed and were ought to promote adoption of the Charter by each nation.

\section{The Ecuadorian case}

If we have a look at two of the Ecuadorian World Heritage Sites - the Historic Centers of Quito and Cuenca - we can see that both urban centers show a very interesting fusion between cultural assets and natural surroundings. Unfortunately they have been the target of inappropriate changes due to the introduction of architecture that does not adapt to the existing landscape, lack of respect for the built scale ant the visuals, newer developments towards mountains slopes, excessive parceling after the land reforms and removal of the vegetation cover generating irreversible soil degradation and the advance of the agricultural frontier at the cost of fragile mountain ecosystems.

The country has been signatory of the UNESCO Convention for the Protection of the World Cultural and Natural Heritage of $1972,{ }^{14}$ which underlines the need to

${ }^{14}$ World Heritage Convention 1972, article 1 
protect the organically evolved landscapes ${ }^{15}$ .Nevertheless no explicit legislation exists that protects these landscapes and in spite of the voices that emphasize the need to protect wider heritage zones, in the national heritage declaration process there is no such figure as "Cultural Landscape". Problems arise when trying to protect areas like the case of Susudel, a rural helmet that has interesting values regarding its history in relationship with its natural landscape as this smal settlement grew from a large landownership that beyond its well conserved historic centre around the original farm buildings and associated chapel, spanned large agricultural lands and commercial relationships with other settlements and cities through its artisanal and agricultural production.

\begin{tabular}{|c|c|c|c|}
\hline & Concepts & Principles & Approaches proposed \\
\hline $\begin{array}{l}\text { Colombia, } \\
\text { 2010, } \\
\text { Sociedad } \\
\text { Colombiana de } \\
\text { Arquitectos } \\
\text { Paisajistas }\end{array}$ & $\begin{array}{l}\text { Landscape is "part of the } \\
\text { territory as it is perceived by } \\
\text { people, and its character results } \\
\text { from the action and interaction } \\
\text { of nature and humans". (Carta } \\
\text { Colombiana del Paisaje, 2010) }\end{array}$ & $\begin{array}{l}\text { Protect the context diversity, memory } \\
\text { and history, character, natural } \\
\text { aspects, habitat and biodiversity, } \\
\text { equity, wellbeing and happiness, } \\
\text { emotional and physical health, } \\
\text { confortable and secure environment, } \\
\text { climate change mitigation. } \\
\text { Responsibility in landscape design and } \\
\text { management }\end{array}$ & $\begin{array}{l}\text { Design; Collaboration; } \\
\text { Education; } \\
\text { Representation; } \\
\text { Research; Evaluation; } \\
\text { Leadership }\end{array}$ \\
\hline $\begin{array}{l}\text { Costa Rica, } \\
2010, \\
\text { Asociación de } \\
\text { Paisajistas de } \\
\text { Costa Rica }\end{array}$ & $\begin{array}{l}\text { "Landscape is a fundamental } \\
\text { component of natural and } \\
\text { cultural heritage, and therefore } \\
\text { also of national and regional } \\
\text { identities." (Carta Costarricense } \\
\text { del Paisaje, 2010) }\end{array}$ & $\begin{array}{l}\text { Community involvement in landscape } \\
\text { planning and for those communities. }\end{array}$ & $\begin{array}{l}\text { To respect the historic } \\
\text { heritage, to grant social } \\
\text { diversity, to foresee and } \\
\text { to control consequences } \\
\text { from development }\end{array}$ \\
\hline $\begin{array}{l}\text { Brasil, 2010, } \\
\text { Asociación de } \\
\text { Arquitectos } \\
\text { Paisajistas de } \\
\text { Brasil }\end{array}$ & $\begin{array}{l}\text { Cultural landscape is all unique } \\
\text { representative portion of the } \\
\text { national territory that show the } \\
\text { process of human interaction } \\
\text { with the natural environment, } \\
\text { in which life and human science } \\
\text { printed marks or attribute } \\
\text { values }\end{array}$ & $\begin{array}{l}\text { Landscape must be accessible to all. } \\
\text { Landscapes and ecosystems must be } \\
\text { recognized. Understand the } \\
\text { relationship between landscape and } \\
\text { people: cultural landscapes. } \\
\text { Landscape is a planning and } \\
\text { sustainable development tool. } \\
\text { Democratic right to environmental } \\
\text { and landscape quality. Integral vision } \\
\text { among landscape projects and } \\
\text { policies. }\end{array}$ & $\begin{array}{l}\text { Landscape analysis and } \\
\text { diagnosis must precede } \\
\text { plans, projects and } \\
\text { interventions. Master, } \\
\text { plans must grant studies } \\
\text { of local landscape. }\end{array}$ \\
\hline $\begin{array}{l}\text { Argentina, } \\
\text { 2010, Centro } \\
\text { Argentino de } \\
\text { Arquitectos } \\
\text { Paisajistas }\end{array}$ & $\begin{array}{l}\text { "Landscape is a social } \\
\text { construction from a cultural } \\
\text { tradition". (Carta Argentina del } \\
\text { Paisaje, 2011) It is in constant } \\
\text { change. }\end{array}$ & & $\begin{array}{l}\text { Analyze and value the } \\
\text { territory from the } \\
\text { landscape perspective. } \\
\text { Management tool that } \\
\text { imbeds historic, cultural, } \\
\text { social and ecologic } \\
\text { values. }\end{array}$ \\
\hline $\begin{array}{l}\text { Chile, 2011, } \\
\text { Instituto } \\
\text { Chileno } \\
\text { Arquitectos } \\
\text { Paisajistas }\end{array}$ & $\begin{array}{l}\text { The landscape understood as a } \\
\text { territorial palimpsest, where } \\
\text { every new process, natural or } \\
\text { human, has a degree of } \\
\text { continuity over the footprints of } \\
\text { the past. The rupture of the } \\
\text { continuity potentially becomes } \\
\text { a negative effect and causes a } \\
\text { sense of uprooting. (Carta } \\
\text { Chilena del Paisaje, 2011) }\end{array}$ & & $\begin{array}{l}\text { Emphasize landscape } \\
\text { social, environmental, } \\
\text { aesthetic and heritage, } \\
\text { productive and economic } \\
\text { dimensions. Take care of } \\
\text { the threats that brings } \\
\text { the global development }\end{array}$ \\
\hline
\end{tabular}

Table 1: Sumary of the most important aspects of the latin american charters of landscape

${ }^{15}$ UNESCO, World Heritage Convention, Operational 


\begin{tabular}{|c|c|c|c|}
\hline & Concepts & Principles & Approaches proposed \\
\hline $\begin{array}{l}\text { Mexico, 2011, } \\
\text { Sociedad de } \\
\text { Arquitectos } \\
\text { Paisajistas de } \\
\text { Mexico }\end{array}$ & $\begin{array}{l}\text { "Landscape is any part of a } \\
\text { territory as perceived by } \\
\text { people, which character is the } \\
\text { result of the action and } \\
\text { interpretation of natural and } \\
\text { human factors". (Carta } \\
\text { Mexicana del Paisaje, 2011, Art. } \\
\text { 2) }\end{array}$ & $\begin{array}{l}\text { Landscape is an element of individual } \\
\text { and collective wellbeing, important } \\
\text { for national identity. Besides aesthetic } \\
\text { and environmental values it has } \\
\text { cultural, social, heritage, economic } \\
\text { dimensions. }\end{array}$ & $\begin{array}{l}\text { Landscape is linked to } \\
\text { sustainable } \\
\text { development. }\end{array}$ \\
\hline $\begin{array}{l}\text { Bolivia, 2011, } \\
\text { Sociedad de } \\
\text { Arquitectos } \\
\text { Paisajistas }\end{array}$ & $\begin{array}{l}\text { "The landscape must be } \\
\text { conserved in all its appearances } \\
\text { because they are an economic, } \\
\text { social and natural asset". (Carta } \\
\text { Boliviana del Paisaje, 2011) }\end{array}$ & $\begin{array}{l}\text { The territory acquires a certain } \\
\text { symbolic value granted by the } \\
\text { cultures that have settled on it. }\end{array}$ & $\begin{array}{l}\text { To take into account the } \\
\text { multicultural diversity of } \\
\text { the country regions and } \\
\text { the activities that affect } \\
\text { landscapes }\end{array}$ \\
\hline $\begin{array}{l}\text { Peru, 2011, } \\
\text { Asociación } \\
\text { Peruana de } \\
\text { Arquitectura } \\
\text { del Paisaje }\end{array}$ & & $\begin{array}{l}\text { Cultural landscapes are a social } \\
\text { production at a territorial scale, a } \\
\text { milestone for the communities and } \\
\text { their identity. }\end{array}$ & \\
\hline
\end{tabular}

Table 1 (continuation): Sumary of the most important aspects of the latin american charters of landscape

Even if authorities recognized the need to protect this historic human settlement and its surroundings as a whole, legally it was only possible to nominate it as a historic centre which obviously weakens its protection. ${ }^{16}$ The National Law of Cultural Heritage (Ley Nacional de Patrimonio Cultural) in force since $1979^{17}$ does not make a clear inclusion of Landscape as a heritage category, but stresses the need for establishing buffer zones, that means to protect: "the building itself and its environmental and scenic surroundings necessary to provide adequate visibility; as well as to keep the atmosphere and integrity in which it was built" ${ }^{18}$

For many years the landscape in its cultural dimension has not been a subject of interest, nevertheless the new Ecuadorian Constitution (2008) has included some articles related to landscape protection. It introduces the Good living ${ }^{19}$ concept, which promotes development together with the imperative respect for traditions and the rights of nature. The article 3 of the constitution states the State's obligation to protect the natural and cultural heritage of the Country. ${ }^{20}$

\footnotetext{
${ }^{16}$ (Oña y Susudel: las historias se convirtieron en patrimonio, 2013)

17 Nowadays the National Gouverment is promoting the creation of a new Culture Law, nevertheless the project does not make any refference to landscape.

18 Ley de Patrimonio Cultural del Ecuador, 1979, Art. 7.

${ }^{19}$ Constitución del Ecuador, 2008, Art. 14.

${ }^{20}$ Constitución del Ecuador, 2008, Art. 3, num.7.

${ }^{21}$ Constitución del Ecuador, 2008, Art. 264 num8.

22 Constitución del Ecuador, 2008, Art. 359, num 2.
}

According to the text the Municipalities have among their exclusive attributions to preserve, maintain, and disseminate the canton's architectural, cultural and natural heritage. ${ }^{21}$ It also includes among the material heritage assets of the Country elements such as natural sites, routes, gardens and landscapes that imbed historic, artistic, archaeological, ethnographic or paleontological value. ${ }^{22}$

Organic Code for Rural Planning, Autonomies and Decentralization (Código Orgánico de Ordenamiento TerritorialAutonomías y Descentralización) (2010), establishes that the decentralized autonomous municipal governments are responsible of the formulation, adoption and implementation of programs and projects aimed at preservation, maintenance and dissemination of architectural, cultural and natural heritage..$^{23}$

As the municipalities are in charge of the management of their territories a great opportunity is created to include both the nature rights and the cultural significance they behold. ${ }^{24}$ In the particular case of the World Heritage City

23 El Código Orgánico de Ordenamiento Territorial Autonomía y Descentralización, 2010, art.144.

${ }^{24}$ To disseminate and promote the respect for nature and cultural values associated with the Good Living, the Sumak Kawsay, cultural landscapes become the most effective too to manage the natural and cultural heritage of the country, consistent with the mandate of constitutional rights of nature, equality representative of different regions and cultures of the country and the integration of all levels of government, including the private sector" (Sarmiento, 2013 36). 
of Cuenca, the local government has already shown interest in including a landscape management approach in its Urban Plan (Plan de Ordenamiento Urbano) (2013) by means of an interdiscilpinary study of the Cultural Landscape of the City. The aim is to produce a document that consists in an instrument for the protection and management of the city's landscape establishing strategies for value assessment and protection. ${ }^{25}$ The draft document is a good starting point for the future management of the cultural landscape of the city of Cuenca. In order to make the diagnosis and value assessment operational studies are to be complemented with specific policies and norms as to the intervention and construction in fragile land units within its territory and that could eventually affect the whole historic city landscape.

Though Cuenca has decided to manage its landscape, this is not the case for most of the Ecuadorian cities, it is common that the municipalities take care of the territory close to the main human settlement, but when it comes to rural areas, the outskirts are ignored for landscape management. This leads to affections and alterations that, even if they are located in the outskirts, most of the time affects the nearby village landscape. Considering the topography of the Andean region which grants amazing views from and towards the cities, these are the first landscape features to be affected.

Besides government institutions two other organizations are interested in conserving the Ecuadorian landscape: the Ecuadorian Society of Landscape Architects (Sociedad de Arquitectos Paisajistas del Ecuador, SAPE) ${ }^{26}$ and the Ecuadorian branch of the International Federation of Landscape Architects (IFLA). ${ }^{27}$
However and in contrast with the IFLA branches in other Latin American countries, landscape protection has not been an issue yet and no soft legislation was promoted by these organizations. Nevertheless it is desirable that these organizations lead the process towards a specific charter for landscape protection adapted to the Ecuadorian reality.

In November 2012, the Academy together with the Ministry of Culture of Ecuador have encouraged the discussion regarding the conceptualization and implementation of the Cultural Landscape as a protection category during the Expert Meeting called "Paisajes Culturales: reflexiones conceptuales y metodológicas". The conclusions and recommendation compiled at the event were the following:

- The notion of Cultural Landscape should be assimilated as a proper strategy for its protection since it integrates cultural and natural heritage, and it requires an interdisciplinary and multicultural approach.

- Suggest the creation of a Heritage National System that define the protection parameters for the declaration of Cultural Landscapes

- The Master Plans should integrate the Cultural Landscape topics and institutionalize its management in the diverse territorial levels.

- Public policies concerning heritage topics should be constructed while adapted to our specific cultural context to propend to identification, value assessment, monitoring and management of cultural landscapes

\begin{tabular}{|c|c|c|}
\hline & Policies & Institutionalization \\
\hline 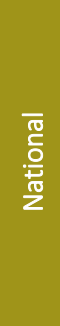 & $\begin{array}{l}\text { Weak } \\
\text { Constitution of Ecuador; Organic Code for Rural } \\
\text { Planning, Autonomies and Decentralization (Código } \\
\text { de Ordenamiento Territorial del Ecuador) } \\
\text { Municipalities Specific Ordinance Plans }\end{array}$ & $\begin{array}{l}\text { Landscape is the exclusive competence of each } \\
\text { municipality, except in the case of Protected Areas } \\
\text { which is the responsibility of the Ministry of } \\
\text { Environment (Ministerio del Ambiente de Ecuador } \\
\text { MAE), National System of Protected Areas (Sistema } \\
\text { Nacional de Áreas Protegidas). Aditionally, but without } \\
\text { legal attributions, there is a Society of Landscape } \\
\text { Architects of Ecuador SAPE (Sociedad de Arquitectos } \\
\text { Paisajistas del Ecuador) }\end{array}$ \\
\hline 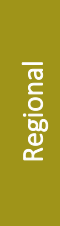 & $\begin{array}{l}\text { Medium } \\
\text { Some policies, without much legal support from each } \\
\text { state. There are national landscape charters } \\
\text { promoted by landscape associations in: Mexico, } \\
\text { Costa Rica, Colombia, Argentina, Chile, Bolivia and } \\
\text { Peru. }\end{array}$ & $\begin{array}{l}\text { The Latin American Landscape Initiative LALI is a } \\
\text { declaration of fundamental ethical principles to } \\
\text { promote the recognition, valuation, protection, } \\
\text { management, and sustainable planning of Latin } \\
\text { American landscapes. (Latin American Landscape } \\
\text { Initiative, 2013) }\end{array}$ \\
\hline
\end{tabular}

Table 2: Comparison among the Ecuadorian, regional and European legislation and a list of the institutions that are in charge of the management of landscapes as well as those that relate to it without any management responsibility.

25 Plan de Ordenamiento Urbano del Cantón Cuenca, Componente Paisajes Culturales (draft), (2013: 25).

\footnotetext{
${ }^{26}$ Sociedad de Arquitectos Paisajistas del Ecuador.

${ }^{27}$ International Federation of Landscape Architects.
} 


\begin{tabular}{|l|l|l|}
\cline { 2 - 3 } \multicolumn{1}{|c|}{ Policies } & \multicolumn{1}{|c|}{ Institutionalization } \\
\hline $\begin{array}{l}\text { Strong } \\
\text { European Landscape Convention; There are specific } \\
\text { national laws regarding landscape, there are some } \\
\text { examples: }\end{array}$ & $\begin{array}{l}\text { UNESCO, Council of Europe, and specific institutions in } \\
\text { each State } \\
\text { Landscape Associations: International Federation of } \\
\text { Landscape Architects }\end{array}$ \\
$\begin{array}{l}\text { Germany: (law for the protection of nature and } \\
\text { Landscape management 1976 modified in 1993) } \\
\text { l. }\end{array}$ & \\
Switzerland:(federal law for the protection of nature \\
and landscape from 1966) \\
$\begin{array}{l}\text { France: (French landscape law) approved in 1993“. } \\
\text { (Askasibar Bereziartua, 1998) } \\
\text { Spain: Valencia Law for the Territorial Ordinance and } \\
\text { Landscape Management from 2004. (Frolova, 2009, p. } \\
\text { 17) }\end{array}$
\end{tabular}

Table 2 (continuation): Comparison among the Ecuadorian, regional and European legislation and a list of the institutions that are in charge of the management of landscapes as well as those that relate to it without any management responsibility.

\section{Comparison and Recommendations}

As to give a further explanation of the elements included in the Table 2, it must be stated that even if landscape is considered into the Ecuadorian constitution and the o Organic Code for Rural Planning, Autonomies and Decentralization, there is no instrumental application of the principles there considered. Furthermore, in this scenario the municipalities cannot make effective contro and empowerment of their competences over landscape, mostly in rural areas.

From the comparison proposed in the table 2 , it becomes evident that there is a week normative corpus in Ecuador which requires attention and decision from the different governmental levels. It is evident that the situation in the region is not much better because even if there are some charters there are still weaknesses in the institutional frame that take care of landscapes.

Latin American legislation has been mostly inspired in the international and European protection policies, but with the particularity of trying to adapt the global trends to the particular development needs that the region is facing. The vision of Cultural Landscape as a way to improve management and to grant wellbeing and promote identity, while respecting a multicultural approach which is part of the regional need, and to include indigenous population into the decisions and management. It would be desirable to count with a regional policy that serves as an umbrella to foster local initiatives.
After the analysis it becomes evident the need to have a clearer legal organization that distributes the competences related to landscape. The national government should also adopt a national law for landscape management and protection, which could also encourage the local governments and specifically those that have to manage cultural landscapes, and Cultural Heritage Sites, such as Cuenca or Quito, to develop their own policies to control building heights, open space/built balance, volumes, urbanization, and mostly to keep the city livable and to guarantee it will keep being the stage of cultural tradition expressions.

It is extremely important that Ecuador takes advantage of the Cultural Landscape approach, while a broader heritage attitude is not included in natural heritage protection Cultural Landscapes are condemned to environmental, contextual distraction without the possibility of a proper management. Cultural Landscape approach allows taking into account all the components including built heritage, nonmaterial heritage, traditional uses and practices, natural environment, identity etc.

Como citar este artículo/How to cite this article: Moscoso, S., Wiiffels, A., Astudillo, S. y Cardoso, F. (2015). Ecuadorian Landscape National legislation contrasted to regional and international landscape policies. Estoa, Revista de la Facultad de Arquitectura y Urbanismo de la Universidad de Cuenca, 4(7), 53-60. doi:10.18537/est.v004.n007.06 


\section{Bibliografía}

- (MAN). (2 de abril de 2013). Oña y Susudel: las historias se convirtieron en patrimonio. Hoy. Recuperado el 28/11/2014 de https://issuu.com/hoycomec/docs/hoy0204a/1 0

- Associação Brasileira de Arquitetos Paisagistas. A Carta Brasileira da Paisagem. Brasil, 2012.

- Asamblea Constituyente del Ecuador. Constitución del Ecuador. Quito, 2008.

- Askasibar Bereziartua, M. Lurralde: investigación y espacio 21 (1998): 155-193. In http://www.ingeba.org/lurralde/lurranet/lur21/21 asca/21aska.htm

- Asociación Peruana de Arquitectura del Paisaje. Perú: Carta del Paisaje. 2011

- Asociación de Paisajistas de Costa Rica. (2010). Carta Costarricense del Paisaje.

- Centro Argentino de Arquitectos Paisajistas. Carta Argentina del Paisaje. (2011).

- Congreso Nacional Ecuador. (1979). Ley de Patrimonio Cultural del Ecuador.

- Council of Europe. (2000). European Landscape Convention.

- First International Congress of Architects and Technicians of Historic Monuments. (1931). The Athens Charter for the Restoration of Historic Monuments.

- Frolova, M. "La evolución reciente de las políticas de paisaje en España y el convenio europeo del paisaje". Proyección, 1(6), (2009): 27.

http://www.bdigital.uncu.edu.ar/objetos_digitales /3457/frolovaproyeccion6.pdf

- ICOMOS. (1964). The Venice Charter

- IFLA. (2013). Towards and International Landscape Convention. Retrieved from http://www.aila.org.au/news/2013/ifla_ilc.pdf

- II Encuentro de Paisajes Culturales. (2012). Carta Iberoamericana de Paisaje Cultural.

- Instituto Chileno Arquitectos Paisajistas. (2011). Carta Chilena del Paisaje.
- International Conference on Conservation in Krakow. (2000). The Charter of Krakow.

- International Federation of Landscape Architects. (n.d.). IFLA. Retrieved July 6, 2014, from http://iflaonline.org/

- Latin American Landscape Initiative. (n.d.). La Iniciativa Lationamericana del Paisaje. Retrieved June 16, 2014, from http://laliniciativablog.files.wordpress.com/201 3/04/lali_en_reducida.pdf

- Latin American Landscape Initiative in http://paisajesculturales.files.wordpress.com/2 013/04/lali_esp_reducido.pdf

- México, S. d. (2011). Carta Mexicana del Paisaje. - Ministerio de Coordinación de la Política y Gobiernos Autónomos Descentralizados. (2010). El Código Orgánico de Ordenamiento Territorial Autonomía y Descentralización.

- Municipalidad de Cuenca. (2013). Plan de Ordenamiento Urbano del Cantón Cuenca, Componente Paisajes Culturales (draft). Cuenca.

- Sarmiento, F. (2013). Paisaje Cultural Patrimonial del Ecuador: Una Categoría de Manejo Territorial. Paisajes Culturales relfexiones conceptuales y metodológicas, Memorias del I Encuentro de Expertos Cuenca, 21,22 y 23 de noviembre del 2012 (pp. 31-43). Cuenca: Ministerio de Cultura.

- Sociedad Colombiana de Arquitectos Paisajistas. (2010). Carta Colombiana del Paisaje.

- Sociedad de Arquitectos Paisajistas del Ecuador. (n.d.). Sociedad de Arquitectos Paisajistas del Ecuador. Retrieved June 24, 2014, from http://laliniciativablog.files.wordpress.com/201 3/07/articulo-para-lali-sape-2013.pdf

- Sociedad de Arquitectos Paisajistas Ecología y Medio Ambiente de Bolivia. (2011). Carta Boliviana del Paisaje.

UNESCO. (1976). Recommendation concerning the Safeguarding and Contemporary Role of Historic Areas 